\title{
STUDI KOMPARASI ANTARA EKSPERIMEN NYATA DENGAN EKSPERIMEN SIMULASI TERHADAP PEMAHAMAN FISIKA PADA POKOK BAHASAN GERAK HARMONIK SEDERHANA
}

\author{
M. Barkah Salim \\ Pendidikan Fisika FKIP Universitas Muhammadiyah Metro \\ Email : barkah_um@yahoo.co.id
}

\begin{abstract}
Providing material in theory and experiments in physics learning to students is very important and must be balanced. Besides that students are aware of a concept that has been created by scientists in physics, but also clear and understood the concept both theoretically and experimentally. In this study, will compare student learning outcomes after a given learning in real experiments and simulation experiments on simple harmonic motion of the subject.

Data collection method used is the questionnaire method tests. Test method consists of pretest and posttest are used to determine students' learning achievement physics. Test instruments used are validity with product moment correlation technique, reliability testing with formula Kuder-Richardson 20 (KR-20), difficulty level test, and test different power. For the prerequisite data analysis in this study to test for normality using the formula Chi-Square and homogeneity test using Bartlett's test. The data obtained are then processed with the hypothesis test using t-test formula.

The results of data analysis showed that there are significant differences between real experimental learning methods with experimental simulation of the physics students' achievement of learning comprehension. This is indicated by the acquisition of the $t$ value of 2.460 while ttable at 5\% significance level with 32 degrees of freedom is 1.691 . The increase in the average score of student achievement (posttest) showed that student achievement using real experimental method 1.77 higher than on student achievement using simulation experiments 0.74, so the proposed hypothesis can be accepted.
\end{abstract}

\section{PENDAHULUAN}

Pemilihan metode yang kurang tepat dalam proses pembelajaran fisika berakibat siswa mengalami kesulitan dalam memahami konsep, karena siswa kurang terlibat dalam proses belajar 
mengajar. Fisika merupakan pelajaran yang cukup sulit. Hingga sekarang masih dirasakan oleh sebagian besar siswa SMA atau sekolah-sekolah sederajat. Indikasinya adalah rendahnya kualitas pendidikan pada umumnya dan fisika pada khususnya.

Sampai saat ini, pembelajaran fisika di sekolah-sekolah lebih diwarnai oleh pendidikan yang menitik beratkan pada pembelajaran konvensional (metode ceramah) sehingga kurang mampu merangsang siswa untuk terlibat aktif dan mengeluarkan ide-ide atau kemampuan berfikir dalam proses pembelajaran. Aktifitas guru lebih menonjol dari pada siswa dan terbatas pada hafalan semata.

Sesungguhnya keberhasilan belajar mengajar dapat ditinjau dari dua faktor, yaitu faktor guru dan faktor siswa. Di samping faktor-faktor tersebut, masih banyak faktor-faktor lain yang mempengaruhi keberhasilan proses belajar mengajar, seperti dorongan belajar dari orang tua, kondisi fisik, kemampuan siswa, latar belakang sosial ekonomi keluarga, fasilitas belajar, dan lain sebagainya. Dalam sistem kurikulum berbasis kompetensi, untuk menunjang pembelajaran yang efektif dan efisien diidentifikasikan ada enam buah karakteristik. Salah satunya adalah sistem pembelajaran dengan menggunakan metode eksperimen.

Eksperimen adalah suatu usaha terencana untuk menjawab sebuah pertanyaan-pertanyaan dengan membuat suatu kegiatan di bawah kondisi-kondisi terkontrol. Tahapan dari pelaksanaan eksperimen dikenal sebagai proses ilmiah (Ishafit, 2004). Menurut Kusumah (2009), metode eksperimen adalah suatu cara pengelolaan pembelajaran di mana siswa melakukan aktivitas percobaan dengan mengalami dan membuktikan sendiri suatu yang dipelajarinya. Dalam metode ini siswa diberi kesempatan untuk mengalami sendiri atau melakukan sendiri dengan mengikuti suatu proses, mengamati suatu obyek, menganalisis, membuktikan dan menarik kesimpulan sendiri tentang obyek yang dipelajarinya. Dari kedua pernyataan di atas, bisa diartikan bahwa, eksperimen merupakan suatu kegiatan dimana siswa mengalami dan membuktikan sendiri hal-hal yang 
M. Barkah Salim - Studi Komparasi Antara Eksperimen ...

diamati di bawah kondisi-kondisi terkontrol.

Menurut Sofa (2008) manfaat sekaligus kelebihan metode eksperimen antara lain menguji hipotesis dengan melakukan kontrol terhadap kondisi penelitian, mengembangkan teori, kemudian melakukan pengujian di lapangan, memperbaiki teori-teori serta temuan-temuan penelitian, meneliti melalui jalan pintas; dan memudahkan replikasi karena kondisi yang dipelajari benar-benar spesifik.

Berdasarkan pelaksanaannya eksperimen dibagi menjadi dua, yaitu eksperimen nyata dan eksperimen simulasi.

Eksperimen nyata merupakan suatu kegiatan yang bertujuan untuk mendapatkan konsep atau fakta dengan menggunakan alat percobaan yang sebenarnya. Kegiatan ini biasanya dilakukan di sebuah laboratorium (Nursidik, 2008).

Eksperimen simulasi merupakan cara menyajikan pengalaman belajar dengan menggunakan situasi tiruan untuk memahami tentang konsep, prinsip, atau fakta (Sanjaya, 2008: 159).
Keseimbangan pemberian materi teori dan eksperimen pada pembelajaran fisika kepada peserta didik sangatlah penting dan haruslah seimbang. Selain agar siswa mengetahui akan suatu konsep yang telah dibuat oleh para ilmuan fisika, tetapi juga paham dan mengerti akan konsep tersebut baik itu menggunakan eksperimen secara nyata ataupun eksperimen secara simulasi. Eksperimen nyata dan eksperimen simulasi merupakan metode pembelajaran secara eksperimen, akan tetapi media yang digunakan berbeda. Pada eksperimen nyata media yang digunakan adalah peralatan laboratorium yang berupa alat, sedangkan pada eksperimen simulasi media yang digunakan berupa software media pembelajaran yang berisi di dalamnya peralatan laboratorium dalam bentuk simulasi.

Dari kedua metode tersebut belumlah diketahui mana yang lebih baik, apakah metode eksperimen nyata, ataukah eksperimen simulasi. Sehingga perlu dilakukan penelitian dengan judul studi komparasi antara eksperimen nyata dengan eksperimen simulasi terhadap 
pemahaman fisika pada pokok bahasan $X_{2}$

gerak harmonik sederhana.

\section{METODE}

Penelitian ini menggunakan disain penelitian Pretest - Postest Control Group, yaitu rancangan yang digunakan dengan cara memberi perlakuan pada jangka waktu tertentu, dan mengukur dengan tes sebelum dan sesudah perlakuan dilakukan (Sofa, 2008). Perlakuan dilaksanakan adalah pembelajaran dengan menggunakan eksperimen nyata pada sampel pertama $\left(A_{1}\right)$ dan eksperimen simulasi pada sampel kedua $\left(A_{2}\right)$.

Adapun desain penelitian tersebut, seperti pada tabel 1:

Tabel 1. Desain Penelitian

\begin{tabular}{|c|c|c|c|}
\hline Kelompok & Pre Test & Perlakuan & Post Test \\
\hline A1 & Y1 & X1 & Y'1 \\
\hline A2 & Y2 & X2 & Y'2 \\
\hline
\end{tabular}

Keterangan :

$Y_{1} \quad$ : kemampuan awal

$Y_{2} \quad$ : sampel kedua

$A_{2} \quad$ : kemampuan akhir

$X_{1} \quad$ : eksperimen nyata

$A_{1} \quad$ : sampel pertama
Adapun populasi dari penelitian ini adalah seluruh siswa kelas XI IPA PIRI 1 Yogyakarta tahun ajaran 2009/2010. Siswa yang menjadi sampel adalah XI IPA 1 dan XI IPA 2.

Teknik pengumpulan data yang digunakan ialah metode tes. Sebelum tes dilakukan harus dilakukan uji instrumen tes, yang terdiri dari uji validitas, uji reliabilitas, uji taraf kesukaran, dan daya beda soal. Setelah uji instrumen dilakukan dan dikatakan layak maka tahapan berikutnya adalah pengumpulan data.

Tahap - tahap pelaksanaan pengum-pulan data terdiri dari 3 tahap, yakni:

- Tahap pertama

Pretest dilakukan sebelum pengajaran dengan menggunakan grup tutorial maupun ceramah, dengan tujuan untuk mengetahui kemampuan awal siswa pada materi pokok bahasan gerak lurus.

- Tahap kedua

Pemberian materi dengan pelaksanaan menggunakan media yang akan digunakan, yaitu eksperimen nyata pada 
kelas pertama $A_{1}$ dan eksperimen $t_{\text {hitung }}>t$ tabel, maka tolak $\left(\mathrm{H}_{0}\right)$ terima simulasi pada kelas kedua $A_{2}$.

$\left(\mathrm{H}_{1}\right)$.

- Tahap ketiga

(Sudjana, 2001: 239)

Posttest dilaksanakan pada akhir

pelajaran setelah pengajaran dengan menggunakan eksperimen nyata maupun dengan eksperimen simulasi, dengan tujuan untuk mengetahui sejauh mana siswa telah paham tentang materi yang telah diberikan dalam pengajaran

Setelah instrumen diuji dan dilaksanakan tahapan selanjutnya dilakukan analisis data. Analisis data yang dilakukan yaitu uji normalitas dan uji homogenitas. Setelah kedua uji tersebut baru bisa dilakukan uji hipotesis menggunakan uji t. Statistik yang digunakan adalah statistk dengan rumus

$$
t=\frac{\bar{x}_{1}-\bar{x}_{2}}{s \sqrt{\frac{1}{n_{1}}+\frac{1}{n_{2}}}}
$$

Standar deviasi diperoleh dengan

$$
s^{2}=\frac{\left(n_{1}-1\right) s_{1}^{2}+\left(n_{2}-1\right) s_{2}^{2}}{n_{1}+n_{2}-2}
$$

Kriteria penyajian :

$t$ hitung $\leq t$ tabel, maka terima $\left(\mathrm{H}_{0}\right)$ tolak $\left(\mathrm{H}_{1}\right)$.

\section{HASIL DAN PEMBAHASAN}

\section{- Hasil uji instrument}

Butir soal tes dalam penelitian ini berjumlah 30 yang di ujikan pada 24 siswa. Berdasarkan analisis uji validitas butir diperoleh hasil bahwa dari 30 butir soal yang diujikan terdapat 22 butir soal yang dinyatakan valid atau sahih ( $r$ hitung $>r$ tabel$)$, dan 8 butir soal dinyatakan gugur ( $r$ hitung $<r$ tabel), pada taraf signifikan $5 \%$ sama dengan 0,404 dengan butir soal yang dinyatakan gugur adalah $6,10,17,18,19,22,25$ dan 28, berjumlah 8 butir. Soal yang gugur tidak akan digunakan untuk menguji kemampuan siswa, sehingga butir soal berjumlah 22 butir soal selanjutnya digunakan sebagai tes dalam penelitian.

\section{- Uji reliabilitas tes}

Reliabilitas butir soal dalam penelitian ini menggunakan uji reliabilitas teknik Kuder Richardson-20 (KR-20) (Arikunto, 2006: 100). Butirbutir soal yang sahih di uji keandalannya 
M. Barkah Salim - Studi Komparasi Antara Eksperimen...

(reliabilitasnya) menggunakan uji dan rata-rata 6,35 sedangkan kelompok reliabilitas. Dari hasil uji reliabilitas siswa yang memperoleh pengajaran instrumen diperoleh nilai $r_{\text {hitung }}=0,886$ dengan menggunakan eksperimen dan $r$ tabel $($ taraf signifikan $5 \%$ 24) $=$ simulasi diperoleh nilai tertinggi 9, 0,404 maka status instrumen soal tes terendah 3, dan rata-rata 5,47. Sedangkan dinyatakan reliabel (andal)

\section{- Uji tingkat kesukaran}

Hasil uji tingkat kesukaran dari 30 soal tes, terdapat 7 butir soal yang tergolong soal sukar $(0<\mathrm{X}<0,30), 21$ butir soal yang tergolong soal sedang $(0,30<X<0,70)$, dan 2 butir soal yang tergolong soal mudah $(0,70<\mathrm{X}<1,0)$.

\section{- Uji daya beda}

Hasil uji daya pembeda soal dari 30 butir soal tes, terdapat 8 soal yang mempunyai indeks diskriminasi jelek $(0,00-0,20), 3$ soal yang mempunyai indeks diskriminasi cukup $(0,21-0,40)$, 17 soal yang mempunyai indeks diskriminasi baik $(0,41-0,70)$, dan 2 soal yang mempunyai indeks diskriminasi baik sekali $(0,71-1,00)$

\section{- Hasil penelitian}

Untuk pretest pada kelompok siswa yang memperoleh pengajaran menggunakan ekspermimen nyata diperoleh nilai tertinggi 10 , terendah 4 , skor posttest pada kelompok siswa yang memperoleh pengajaran menggunakan eksperimen nyata diperoleh nilai tertinggi 11 , terendah 5 , dan rata-rata 8,12. Dan kelompok siswa yang memperoleh pengajaran dengan menggunakan eksperimen simulasi diperoleh nilai tertinggi 12 , terendah 3 , dan rata-rata 6,17. Ringkasan hasil perolehan skor tertera pada Tabel 2 dan Tabel 3.

Tabel 2. Ringkasan nilai tes prestasi belajar fisika (pretest)

\begin{tabular}{|c|c|c|c|c|}
\hline \multirow{2}{*}{$\mathrm{N}$} & & \multicolumn{3}{|c|}{ Parameter } \\
\cline { 3 - 5 } $\mathrm{o}$ & Sampel & $\begin{array}{c}\text { Tertingg } \\
\mathrm{i}\end{array}$ & $\begin{array}{c}\text { Terenda } \\
\mathrm{h}\end{array}$ & $\begin{array}{c}\text { Rata } \\
\text {-rata }\end{array}$ \\
\hline 1 & $\begin{array}{c}\text { Eksperime } \\
\text { n nyata }\end{array}$ & 10 & 4 & 6,35 \\
\hline 2 & $\begin{array}{c}\text { Eksperime } \\
\text { n simulasi }\end{array}$ & 9 & 3 & 5,47 \\
\hline
\end{tabular}

Tabel 3. Ringkasan nilai tes prestasi belajar fisika (Post Test)

\begin{tabular}{|l|l|l|l|l|}
\hline \multirow{2}{*}{$\begin{array}{l}\mathrm{N} \\
\mathrm{o}\end{array}$} & Sampel & \multicolumn{3}{|l|}{ Parameter } \\
\cline { 3 - 5 } & $\begin{array}{l}\text { Tertingg } \\
\mathrm{i}\end{array}$ & $\begin{array}{l}\text { Terenda } \\
\mathrm{h}\end{array}$ & $\begin{array}{l}\text { Rata } \\
\text {-rata }\end{array}$ \\
\hline 1 & $\begin{array}{l}\text { Eksperime } \\
\text { n nyata }\end{array}$ & 11 & 5 & 8,12 \\
\hline 2 & $\begin{array}{l}\text { Eksperime } \\
\text { n simulasi }\end{array}$ & 12 & 3 & 6,17 \\
\hline
\end{tabular}


Dari Tabel 2 dan Tabel 3, dapat

diringkas hasil perolehan rara-rata sekor pada kedua sampel seperti tertera pada

Tabel 4.

Tabel 4. Ringkasan perolehan nilai rata-

\begin{tabular}{|c|c|c|c|c|}
\hline $\begin{array}{l}\text { Kelompo } \\
\mathrm{k}\end{array}$ & $\begin{array}{l}\text { Prete } \\
\text { st }\end{array}$ & $\begin{array}{l}\text { Treatm } \\
\text { ent }\end{array}$ & $\begin{array}{l}\text { Postte } \\
\text { st }\end{array}$ & $\begin{array}{l}\text { Kenaik } \\
\text { an nilai }\end{array}$ \\
\hline $\begin{array}{l}\text { Eksperi } \\
\text { men } \\
\text { nyata }\end{array}$ & $\begin{array}{l}\bar{x}= \\
6,35\end{array}$ & $X_{1}$ & $\begin{array}{l}\bar{x}= \\
8,12\end{array}$ & 1,77 \\
\hline $\begin{array}{l}\text { Eksperi } \\
\text { men } \\
\text { simulasi }\end{array}$ & $\begin{array}{c}\bar{x}= \\
5,47\end{array}$ & $X_{2}$ & $\begin{array}{l}\bar{x}= \\
6,17\end{array}$ & 0,74 \\
\hline
\end{tabular}

Apa bila melihat kenaikan rata-

rata nilai pretest ke posttest seperti terterara pada Tabel 4, dapat disimpulakan bahwa kenaikan nilai yang diperoleh oleh eksperimen nyata lebih baik dari pada eksperimen simulasi.

\section{- Uji normalitas}

Uji normalitas dilakukan dengan tujuan untuk mengetahui distribusi atau sebaran data normal atau tidak. Pada penelitian ini menggunakan uji chi kuadrat $\left(\chi^{2}\right), \quad$ dengan ketentuan distribusi normal jika $\chi^{2}{ }_{\text {hitung }} \leq \chi^{2}{ }_{\text {tabel }}$. Ringkasan hasil uji normalitas dapat dilihat pada Tabel 5 dan Tabel 6 .
Tabel 5. Hasil uji normalitas nilai kemampuan awal

\begin{tabular}{|c|c|c|c|c|c|}
\hline Sampel & $\begin{array}{c}\text { Taraf } \\
\text { Signifik } \\
\text { an }\end{array}$ & $\begin{array}{c}\chi^{2} \\
\text { hitun } \\
g\end{array}$ & $\begin{array}{c}\chi^{2} \\
\text { tabel }\end{array}$ & $\begin{array}{c}\mathrm{d} \\
\mathrm{k}\end{array}$ & $\begin{array}{c}\text { Distrib } \\
\text { usi }\end{array}$ \\
\hline $\begin{array}{c}\text { Eksperi } \\
\text { men } \\
\text { nyata }\end{array}$ & $5 \%$ & $\begin{array}{c}1,8 \\
8\end{array}$ & $\begin{array}{c}3,48 \\
1\end{array}$ & 1 & normal \\
\hline $\begin{array}{c}\text { Eksperi } \\
\text { men } \\
\text { simulasi }\end{array}$ & $5 \%$ & $\begin{array}{c}1,4 \\
6\end{array}$ & $\begin{array}{c}3,48 \\
1\end{array}$ & 1 & normal \\
\hline
\end{tabular}

Hasil perhitungan uji normalitas sebagaimana ditampilkan pada Tabel 6 , diperoleh nilai $\chi^{2}{ }_{\text {hitung }}$ kemampuan awal untuk eksperimen nyata 1,88 dengan $\chi^{2}$ tabel pada taraf signifikan $5 \%$ dan dk 1 sebesar 3,481 dengan demikian sesuai dengan ketentuan, maka data berdistribusi normal. Sedangkan nilai $\chi^{2}$ hitung kemampuan awal untuk kelas eksperimen simulasi 1,46 dengan $\chi^{2}$ tabel pada taraf signifikan $5 \%$ dan dk 1 sebesar 3,481 dengan demikian sesuai dengan ketentuan, maka data berdistribusi normal.

Tabel 6. H uji normalitas nilai kemampuan akhir

\begin{tabular}{|c|c|c|c|c|c|}
\hline Sampel & $\begin{array}{c}\text { Taraf } \\
\text { Signif } \\
\text { ikan }\end{array}$ & $\begin{array}{c}\chi^{2} \\
\text { hitung }\end{array}$ & $\begin{array}{c}\chi^{2} \\
\text { tabel }\end{array}$ & $\begin{array}{c}\mathrm{d} \\
\mathrm{k}\end{array}$ & $\begin{array}{c}\text { Distrib } \\
\text { usi }\end{array}$ \\
\hline $\begin{array}{c}\text { Eksperimen } \\
\text { nyata }\end{array}$ & $5 \%$ & 2,67 & 3,481 & 1 & normal \\
\hline $\begin{array}{c}\text { Eksperimen } \\
\text { simulasi }\end{array}$ & $5 \%$ & 0,07 & 3,481 & 1 & normal \\
\hline
\end{tabular}


$\chi^{2}$ tabel pada taraf $5 \%$ dan $\mathrm{db} 1$ sebesar

Hasil perhitungan uji normalitas sebagaimana ditampilkan pada Tabel 6 , diperoleh nilai $\chi^{2}$ hitung kemampuan akhir untuk eksperimen nyata 2,67 dengan $\chi^{2}$ tabel pada taraf signifikan $5 \%$ dan $\mathrm{dk} 1$ sebesar 3,481 dengan demikian sesuai dengan ketentuan, maka data berdistribusi normal. Sedangkan nilai $\chi^{2}$ hitung kemampuan akhir untuk kelas eksperimen simulasi 0,07 dengan $\chi^{2}$ tabel pada taraf signifikan $5 \%$ dan $\mathrm{dk} \quad 1$ sebesar 3,481 dengan demikian sesuai dengan ketentuan, maka data berdistribusi normal.

\section{- Uji homogenitas}

Uji homogenitas dalam penelitian ini dengan menggunakan uji Bartlet. Ringkasan uji homogenitas adalah sebagaimana pada Tabel 7.

Tabel 7. Uji homogenitas kemampuan

\begin{tabular}{|c|c|c|c|c|c|}
\hline $\begin{array}{c}\text { Variab } \\
\text { el }\end{array}$ & $\begin{array}{c}\text { Taraf } \\
\text { Signifik } \\
\text { an }\end{array}$ & $\begin{array}{c}\chi^{2} \\
\text { hitun } \\
g\end{array}$ & $\begin{array}{c}\chi^{2} \\
\text { tabel }\end{array}$ & $\begin{array}{c}\mathrm{d} \\
\mathrm{b}\end{array}$ & $\begin{array}{c}\text { Distribu } \\
\text { si }\end{array}$ \\
\hline $\mathrm{Y}$ & $5 \%$ & $\begin{array}{c}0,0 \\
5\end{array}$ & $\begin{array}{c}3,84 \\
1\end{array}$ & 1 & $\begin{array}{c}\text { homoge } \\
\mathrm{n}\end{array}$ \\
\hline
\end{tabular}

Dari Tabel 7, dapat dilihat bahwa nilai $\chi^{2}$ hitung sebesar 0,05 sedangkan untuk
3,841 sehingga bisa diambil kesimpulan bahwa sampel berasal dari populasi yang homogen.

Tabel 8. Uji homogenitas kemampuan akhir berupa nilai posttest

\begin{tabular}{|c|c|c|c|c|c|}
\hline $\begin{array}{c}\text { Variab } \\
\text { el }\end{array}$ & $\begin{array}{c}\text { Taraf } \\
\text { Signifik } \\
\text { an }\end{array}$ & $\begin{array}{c}\chi^{2} \\
\text { hitun } \\
\mathrm{g}\end{array}$ & $\begin{array}{c}\chi^{2} \\
\text { tabel }\end{array}$ & $\begin{array}{c}\mathrm{d} \\
\mathrm{b}\end{array}$ & $\begin{array}{c}\text { Distribu } \\
\mathrm{si}\end{array}$ \\
\hline $\mathrm{Y}$ & $5 \%$ & $\begin{array}{c}3,2 \\
2\end{array}$ & $\begin{array}{c}3,84 \\
1\end{array}$ & 1 & $\begin{array}{c}\text { homoge } \\
\mathrm{n}\end{array}$ \\
\hline
\end{tabular}

Dari tabel 8, dapat dilihat bahwa nilai $\chi^{2}$ hitung sebesar 3,22 sedangkan untuk $\chi^{2}$ tabel pada taraf $5 \%$ dan db 1 sebesar 3,841 sehingga bisa diambil kesimpulan bahwa sampel berasal dari populasi yang homogen.

\section{- Uji hipotesis}

Apabila sampel berasal dari populasi yang berdistribusi normal dan homogen, maka dapat dilakukan uji hipotesis. Untuk analisis uji-t digunakan hasil dari posttest.. Ringkasan hasil analisis uji-t antara kelas eksperimen dengan kelas kontrol dapat dilihat pada tabel sebagai berikut:

Tabel 9. Ringkasan hasil uji-t

\begin{tabular}{|c|c|c|c|c|}
\hline $\mathrm{dk}$ & $\begin{array}{c}\text { Taraf } \\
\text { signifikan }\end{array}$ & $t_{\text {hitung }}$ & $t_{\text {tabel }}$ & kesimpulan \\
\hline 32 & $5 \%$ & 2,460 & 1,691 & $\mathrm{H}_{\mathrm{o}}$ ditolak \\
\hline
\end{tabular}


dalam persen sebesar $8,85 \%$ dan $3,30 \%$.

Pada tabel 9, perhitungan diperoleh nilai $t$ hitung sebesar 2,460 sedangkan $t$ tabel dengan derajat kebebasan 32 dan derajat kebermaknaan 0,05 atau taraf signifikan $5 \%$ adalah 1,691. Jadi kesimpulannya $t_{\text {hitung }}>t_{\text {tabel}}$, dengan demikian $\mathrm{H}_{0}$ ditolak. Hal ini menunjukkan bahwa pembelajaran Fisika dengan eksperimen nyata dan eksperimen simulasi mempunyai memiliki perbedaan dalam meningkatkan pemahaman siswa.

\section{- Pembahasan}

Dari uji hipotesis sebagaimana ditampilkan pada tabel 9, diketahui adanya perbedaan peningkatan prestasi antara eksperimen nyata dengan eksperimen simulasi. Peningkatan prestasinya rata-rata dari siswa yang menggunakan metode eksperimen lebih besar dari pada peningkatan prestasi rata-rata siswa yang menggunakan metode simulasi sebagaimana ditampilkan pada tabel 4, yaitu sebesar 1,77 dan 0,74 atau jika dinyatakan JPF. Vol. III. No. 1. Maret 2015
Walaupun peningkatan sebesar nilai tersebut belum terlalu besar, namun perbedaan peningkatan prestasi antara kedua metode cukup signifikan. Metode eksperimen nyata lebih unggul untuk meningkatkan prestasi karena siswa langsung terlibat dalam eksperimen riil, sehingga lebih mudah memahami masalah yang diteliti. Hal ini berdampak pada kemudahan untuk menghubungkan teori dengan praktek sehingga dari data yang didapat lebih menuntun kepada siswa untuk melakukan analisis secara benar.

\section{PENUTUP}

\section{Kesimpulan}

Berdasarkan hasil penelitian dan analisis data yang telah dilakukan maka dapat diambil kesimpulan bahwa:

- Terdapat perbedaan antara pembelajaran dengan menggunakan 
metode eksperimen nyata dan eksperimen simulasi.

- Pembelajaran dengan menggunakan eksperimen nyata lebih efektif dari pada eksperimen simulasi.

\section{Saran}

- Metode eksperimen yang dapat digunakan dalam meningkatkan pemahaman siswa ada dua macam yaitu eksperimen nyata dan eksperimen simulasi. Memang tidak semudah konvensionel, tetapi siswa lebih senang dan aktif didalam kelas

- Apabila ingin meakukan pembelajaran menggunakan metode eksperimen, lebih efektif menggunakan eksperimen nyata.

\section{DAFTAR PUSTAKA}

Sofa. 2008. Metode Penelitian Komunikasi Bag 2. http://massofa.wordpress.com/ 2008/01/25/metode-penelitiankomunikasi-bag-2/

Sudjana. 2001. Metode Statistika. Bandung : Tarsito.

Kusumah, Wijaya. 2009. MacamMacam Metode Pembelajaran. http://public. kompasiana.com/2009/06/08/maca m-macam-metode-pembelajaran/
Ishafit. 2004. Teori Pengukuran dan Eksperimen Fisika. Yogyakarta: FKIP UAD

Nursidik, Yahya. 2008. Kumpulan Metode

Pembelajaran/Pendampingan. Bandung: Google. http://apadefinisinya.blogspot.com/ 2008/05/kumpulan-metodepembelajaranpendampinga.html

Sanjaya, Wina. 2008. Strategi Pembelajaran Berorientasi Setandar Proses Pendidikan. Edisi I cetakan ke-4. Jakarta : Kencana. 